Annals of Plant and Soil Research 23(2): 219-222 (2021)

https://doi.org/10.47815/apsr.2021.10061

\title{
Effect of organic inputs and mulching on growth and yield of roselle (Hibiscus sabdariffavar. sabdariffa)
}

\author{
S.A. SINDHU BHARADHI, K. HARIPRIYA AND S. KAMALAKANNAN* \\ Department of Horticulture, Faculty of Agriculture, Annamalai University, $\quad$ Annamalainagar- 608 \\ 002, Tamilnadu, India.
}

Received; December, 2020, Revised and accepted; February, 2021

\begin{abstract}
A field experiment was carried out on a farmer's field at Kannitamilnadu village in Cuddalore district, Tamilnadu during 2018 to find out the suitable organic inputs and pattern of mulching for better growth and yield of roselle (Hibiscus sabdariffavar. sabdariffa). The experiment was laid out in a factorial randomized block design with five levels of organic manures and four levels of mulching with three replication.. Best of the interaction effect was due to the combined application of $25 t F Y M+3 t$ poultry manure ha ${ }^{-1}+$ plastic mulch $\left(M_{3} S_{2}\right)$ which recorded the highest values for all growth and yield parameters viz., plant height $(228.3 \mathrm{~cm})$, number of branches (14.5), leaf area $\left(308.9 \mathrm{~cm}^{2}\right)$, number of calcyes/plant (33.5), calyx yield/plant (233.9 g) and calyx yield/ha $(6568.75 \mathrm{~kg})$. The lowest values of these parameters were recorded under control (no organics and no mulching) treatment,
\end{abstract}

Keywords: Roselle,organic manures, mulching, growth, yield.

\section{INTRODUCTION}

Roselle (Hibiscus sabdariffa var. sabdariffa) is a highly nutritious but less popular vegetable that belongs to the family Malvaceae. The product of interest is the fleshy reddish brown calyx surrounding the fruit. This part is called roselle which are utilised to make sauce, juice, syrup, jam, marmalade, relish, chutney, jelly and wine. The dried calyces are used in the preparation of tea as they are rich in antioxidants, vitamins and minerals besides adding natural colour to the products. There is a large demand for fresh organic roselle in the national market also. Increasing yield is the most important economic goal of farmers. Increasing costs of chemical inputs and then ill effects have left farmers to adopt age old traditional farming with organic inputs. Organic manures play a major role in supplying macro and micronutrients, besides improving the water retention in soil which inturn increase the yield of crops. Organic manures like farmyard manure, poultry manure, neem cake and vermicompost helps to maintain the soil fertility, reduce the environmental pollution increases the yield and improves the quality of agricultural crops. (Patidar and Mali 2004). Poultry manure is an excellent source of nitrogen and other nutrients. Besides the nutrient content, it also increases the water holding capacity, bulk density, porosity, infiltration capacity and regulates soil temperature. Being completely natural, neem cake is compatible with soil microbes, nurtures healthy bacteria and ensures stronger texture, higher water holding capacity and aeration in the soil, contributing towards better root development. Vermicompost has higher nutrient value and act as a rich source of nutrients. It possess outstanding biological properties and have microbiological populations significantly larger and more diverse when compared to conventional composts.

The practice of mulching leads to several advantages like nutrient recycling, control of erosion besides weed suppression. Mulches cover the soil surface around the plants to create congenial condition for the plant growth. Regulation of temperature and salinity reduction is the desirable effects of mulching. It also exerts decisive effects on earliness, yield and quality of the crops. In addition, mulches reduce evaporation of water from soil surface. Different mulches when combined with organic amendments would definitely boost the biocidal activity during decomposition of organic materials. (Adekiya et al. 2017). Thus, there is a good scope for increasing the yield of roselle under organic production system. Hence, the present investigation was formulated to study the 
growth and yield parameters of roselle as influenced by organic amendments and mulching pattern.

\section{MATERIALS AND METHODS}

Experiment was conducted during 2018 at the farmer field at kannitamilnadu, Cuddalore district of Tamil Nadu. Geographically, the site is located at $11.59^{\circ} \mathrm{N}$ latitude, $79.60^{\circ} \mathrm{E}$ Longitude and at an altitude of $+9.0 \mathrm{~m}$ above sea level. The soil had a pH of 6 , organic carbon of $5.1 \mathrm{~g} \mathrm{~kg}^{-1}$, available nitrogen $142 \mathrm{~kg} \mathrm{ha}{ }^{-1}$, available phosphorus of $60 \mathrm{~kg} \mathrm{ha}$ and available potassium of $200 \mathrm{~kg} \mathrm{ha}^{-1}$. The five levels of organic manures including control, $50 \mathrm{t} \mathrm{FYM} \mathrm{ha-}$ 1,25 t FYM + 3 t poultry manure ha ${ }^{-1}, 25$ t FYM +4 t neem oil cake ha- ${ }^{-1}, 25$ t FYM ha $^{-1}+5 \mathrm{t}$ vermicompost ha- ${ }^{-1}$ and four levels of mulching comprising control, plastic mulch, paddy straw mulch (15 cm thickness) and sugarcane trash mulch (15 cm thickness) evaluated in factorial randomized block design with three replications. At the time of last ploughing, FYM, poultry manure, neem cake and vermicompost were incorporated into the soil as per the treatments. Quantity of FYM incorporated was $25 \mathrm{t} \mathrm{ha}^{-1}$ in all treatments except treatment with FYM alone. Organic manures like poultry manure, neem oil cake, vermicompost were applied as basal (50\%) and in two split doses at 25 DAS (25\%) and 45 DAS (25\%). Ridges and furrows were formed at a spacing of $100 \mathrm{~cm}$ and the seeds were sown at a spacing of $60 \mathrm{~cm}$. Roselle seeds of native ideotype collected from Uttar Pradesh was used.Mulches were laid seven days after sowing. The crop was irrigated once or twice in a week depending upon the soil moisture and weather conditions. Crop was maintained according to the standards for a duration of 150 days. Calyces were harvested using clippers and weighed. Observations were recorded on different growth and yield attributes. In each treatment, five plants were selected at random. Selected plants were tagged for the purpose of recording observationsviz., plant height, number of branches, leaf area, number of calyces per plant, calyces yield per plant and calyces yield per hectare. The data were statistically analysed as per procedure of Panse and Sukhatme (1978).The DOSboxAgdata software was used for the statistical analysis.

\section{RESULTS AND DISCUSSION}

\section{Growth characters}

From the results (Table 1) it was observed that application of organic inputs had significant influence on growth characters in roselle. Among the organic inputs, application of 25 t FYM + 3 t Poultry manure ha ${ }^{-1}$ recorded the highest plant height at 120 DAS $(209.0 \mathrm{~cm})$, maximum number of branches (12.7) and leaf area $\left(301.9 \mathrm{~cm}^{2}\right)$. This was followed by the treatment $25 \mathrm{t} F Y M+4 \mathrm{t}$ neem oil cake ha ${ }^{-1}$. Significant differences were exhibited due to mulching. Among the mulches, plastic mulch registered the highest value for plant height at 120 DAS $(199.6 \mathrm{~cm})$, maximum number of branches at 80 DAS (11.6) and leaf area (298.5 $\mathrm{cm}^{2}$ ).

Table 1: Effect of organic inputs and mulching on plant height at 120 DAS and number of branches at 80 DAS in roselle

\begin{tabular}{|c|c|c|c|c|c|c|c|c|c|c|}
\hline \multirow[b]{2}{*}{ Treatments } & \multicolumn{5}{|c|}{ Plant height $(\mathrm{cm})$} & \multicolumn{5}{|c|}{ Number of branches } \\
\hline & Control & Plastic & $\begin{array}{l}\text { Paddy } \\
\text { straw }\end{array}$ & $\begin{array}{c}\text { Sugarcane } \\
\text { trash }\end{array}$ & Mean & Control & Plastic & $\begin{array}{l}\text { Paddy } \\
\text { straw }\end{array}$ & $\begin{array}{c}\text { Sugarcane } \\
\text { trash }\end{array}$ & Mean \\
\hline Control & 147.8 & 162.6 & 152.5 & 157.9 & 155.2 & 6.1 & 7.7 & 6.8 & 7.1 & 6.9 \\
\hline 50 t FYM ha ${ }^{-1}$ & 166.4 & 176.6 & 171.7 & 171.4 & 171.5 & 8.1 & 9.5 & 9.1 & 8.9 & 8.9 \\
\hline $25 \mathrm{t} \mathrm{FYM} \mathrm{+} 3 \mathrm{t} \mathrm{PM} \mathrm{ha}^{-1}$ & 186.4 & 228.3 & 198.3 & 223.3 & 209.1 & 10.8 & 14.5 & 11.6 & 13.9 & 12.7 \\
\hline $25 \mathrm{t} \mathrm{FYM} \mathrm{+} 4 \mathrm{t} \mathrm{NC} \mathrm{ha}^{-1}$ & 184.5 & 220.3 & 210.5 & 195.5 & 202.7 & 10.6 & 13.5 & 12.9 & 11.4 & 12.1 \\
\hline $25 \mathrm{tFYM}+5 \mathrm{tVC}^{-1}$ & 181.5 & 210.5 & 198.3 & 206.1 & 199.1 & 10.1 & 12.8 & 11.9 & 12.4 & 11.8 \\
\hline Mean & 173.3 & 199.6 & 186.3 & 190.9 & & 9.2 & 11.6 & 10.5 & 10.7 & \\
\hline$C D(P=0.05)$ & M 1.06, & 0.95 & & $M \times S 2.13$ & & M 0.10, & S 0.09 & & M X S 0.21 & \\
\hline
\end{tabular}

FYM - farm yard manure, $P M$ - poultry manure, $N C$ - neem cake, VC-vermicompost

The lowest values for plant height, number of branches and leaf area were observed in control. Combined application of organic inputs and mulching also showed 
significant differences and 25 t FYM +3 t poultry manure $\mathrm{ha}^{-1}+$ plastic mulching recorded the highest plant height of $228.3 \mathrm{~cm}$ at 120 DAS, maximum number of branches at 80 DAS (14.4) and leaf area $\left(308.8 \mathrm{~cm}^{2}\right)$. This was followed by 25 t FYM +3 t poultry manure ha ${ }^{-1}+$ sugarcane trash mulch and the lowest values were observed in control. The plots incorporated with neem oil cake, vermicompost also produced more number of branches and leaf area than control. The positive response in growth characters may be due to the synergistic effect of FYM and poultry manure in making plant nutrients more available by improving, physical and chemical conditions of soil and by solubilizing the nutrients. The increase in the growth may also be due to addition of $\mathrm{N}$ from the organic manures which would be responsible for promoting plant height (Kujur et al., 2016). The positive effect on plant height of roselle due to farmyard manure and poultry manure is in line with the findings of Arsham (2013) who indicated that application of $20 \mathrm{t} \mathrm{ha}^{-1}$ of poultry manure resulted in the tallest roselle plant. The increase in number of branches might be attributed to increased supply of numerous plant nutrients from farmyard manure to the plants, which might have promoted the growth of lateral shoots. This result is in agreement with the findings of Atta et al. (2011). In roselle crop, plastic mulching exhibited benefits in respect of growth parameters. It reduced weed population resulting in less competition of weeds with plants making more availability of nutrients to the plant. Similar findings were reported by Awodoyinet al. (2007) in tomato and Kamalakannanet al. (2019) in okra.

Table. 2. Effect of organic inputs and mulching on leaf area and number of calyces/ plant in roselle

\begin{tabular}{|c|c|c|c|c|c|c|c|c|c|c|}
\hline \multirow[b]{2}{*}{ Treatments } & \multicolumn{5}{|c|}{ Leaf area $(\mathrm{cm} 2)$} & \multicolumn{5}{|c|}{ Number of calyces/ plant } \\
\hline & Control & Plastic & $\begin{array}{l}\text { Paddy } \\
\text { straw }\end{array}$ & $\begin{array}{c}\text { Sugarcane } \\
\text { trash }\end{array}$ & Mean & Control & Plastic & \begin{tabular}{|l|} 
Paddy \\
straw
\end{tabular} & $\begin{array}{c}\text { Sugarcane } \\
\text { trash }\end{array}$ & Mean \\
\hline $\begin{array}{l}\text { Control } \\
50 \text { t FYM ha } \\
25 \text { t FYM + } 3 \text { t PM ha-1 } \\
25 \text { t FYM + 4 } \text { h NC }^{-1} a^{-1} \\
25 \text { t FYM + } 5 \text { t VC } \text { ha }^{-1} \\
\text { Mean } \\
C D(P=0.05)\end{array}$ & $\begin{array}{l}279.6 \\
287.7 \\
295.3 \\
295.3 \\
293.4 \\
290.3 \\
M 0.11, \varsigma\end{array}$ & $\begin{array}{r}285.6 \\
291.6 \\
308.9 \\
304.3 \\
302.5 \\
298.6 \\
\text { S } 0.10\end{array}$ & $\begin{array}{l}281.7 \\
289.4 \\
297.4 \\
302.4 \\
297.4 \\
293.7\end{array}$ & $\begin{array}{c}283.7 \\
289.4 \\
306.3 \\
295.7 \\
299.6 \\
294.9 \\
\text { M X S 0.22 }\end{array}$ & $\begin{array}{l}282.6 \\
289.5 \\
301.9 \\
299.5 \\
298.2\end{array}$ & $\begin{array}{c}9.7 \\
13.6 \\
16.3 \\
18.5 \\
15.4 \\
14.7 \\
M 0.16\end{array}$ & $\begin{aligned} 12.4 \\
14.7 \\
33.5 \\
22.5 \\
18.2 \\
20.3 \\
S 0.14\end{aligned}$ & $\begin{array}{c}9.8 \\
14.5 \\
15.3 \\
20.3 \\
20.3 \\
16.0\end{array}$ & $\begin{array}{c}10.6 \\
12.6 \\
22.5 \\
19.3 \\
16.7 \\
16.4 \\
\mathrm{M} \times \mathrm{S} 0.32\end{array}$ & $\begin{array}{l}10.6 \\
13.9 \\
21.9 \\
20.2 \\
17.6\end{array}$ \\
\hline
\end{tabular}

\section{Yield attributes and yield}

Yield is a complex phenomenon which can be manipulated by various genetic factors and cultural operations. The combined effect of organic inputs and mulching produced significant differences for number of calyces per plant. Among the interactions, application $25 \mathrm{t} \mathrm{FYM} \mathrm{+} 3$ t poultry manure ha ${ }^{-1}$ and plastic mulch gave the maximum number of calyces per plant (33.4). This increase in number of calyces/ plant might be due to the increased number of branches. The lowest mean number of calyces per plant was observed in control plot (9.7). The higher calyx yield ha ${ }^{-1}\left(6.5 \mathrm{t} \mathrm{ha}^{-1}\right)$ was recorded with $25 \mathrm{t}$ $\mathrm{FYM}+3$ t poultry manure ha ${ }^{-1}$ and plastic mulch. Application of neem cake and vermicompost also expressed significance improvement in growth and yield of roselle. The maximum yield of calyces plant ${ }^{-1}(233.9 \mathrm{~g})$ was recorded in plots which received $25 \mathrm{t} \mathrm{FYM}+3$ t poultry manure $\mathrm{ha}^{-1}$ and subjected to plastic mulching. The yield of the plant is attributed to the capability of plant roots to take up available nutrients from the soil. High yield in response to farmyard manure and poultry manure was ascribed to improvement in physical and biological properties of the soil, which might have resulted in better supply of adequate amount of nutrients in the right proportion leading to enhanced crop growth and yield. The least competition from weeds throughout the growing season might be the reason for better performance of roselle under black polythene mulch. The highest yield increased by $66.3 \%$ over control by mulching with plastic sheet. Haruna et al. (2011) in roselle found that $5 \mathrm{t} \mathrm{ha} \mathrm{h}^{-1}$ of poultry manure with $60 \mathrm{~kg}$ $\mathrm{ha}^{-1}$ of inorganic fertilizers significantly increased calyx yield. Similar findings were reported by Thangamuniyandi and Kamalakannan (2016) in Ashgourd. Neem oil cake supplies macro and micro nutrients to plants which aids in the growth and development of crop plants. In addition, it contains alkaloids nimbin and nimbidin which have nitrification inhibiting properties and release $\mathrm{N}$ slowly. resulted in the extended period of 
nutrient availability for the entire duration of crop. The yield of calyces with neem cake was better than in control plots. Vermicomposting is the most eco- friendly organic manure which makes the nutrients easily available to the plants. The leachates from the vermicompost would have stimulated the growth and yield of roselle plants.

Table 3: Effect of organic inputs and mulching on calyx yield in roselle

\begin{tabular}{|c|c|c|c|c|c|c|c|c|c|c|}
\hline \multirow[b]{2}{*}{ Treatments } & \multicolumn{5}{|c|}{ Calyx yield per plant $(\mathrm{g})$} & \multicolumn{5}{|c|}{ Calyx yield per hectare $\left(\mathrm{t} \mathrm{ha}^{-1}\right)$} \\
\hline & Control & Plastic & $\begin{array}{l}\text { Paddy } \\
\text { straw }\end{array}$ & $\begin{array}{c}\text { Sugarcane } \\
\text { trash }\end{array}$ & Mean & Control & Plastic & $\begin{array}{l}\text { Paddy } \\
\text { straw }\end{array}$ & $\begin{array}{c}\text { Sugarcane } \\
\text { trash }\end{array}$ & Mean \\
\hline $\begin{array}{l}\text { Control } \\
50 \text { t FYM ha } \\
25 \text { t FYM + } 3 \text { t PM ha }{ }^{-1} \\
25 \text { t FYM + } 4 \text { t NC } \text { ha }^{-1} \\
25 \text { t FYM + 5 t VC } \text { ha }^{-1} \\
\text { Mean } \\
C D(P=0.05)\end{array}$ & $\begin{array}{c}77.6 \\
108.9 \\
128.4 \\
130.9 \\
123.4 \\
113.9 \\
\text { M } 3.22\end{array}$ & $\begin{array}{l}101.5 \\
118.6 \\
233.9 \\
181.6 \\
172.2 \\
161.6 \\
S 2.97 \\
\end{array}$ & $\begin{array}{c}89.3 \\
113.3 \\
121.1 \\
161.5 \\
141.7 \\
125.4\end{array}$ & $\begin{array}{c}95.9 \\
114.1 \\
205.1 \\
134.0 \\
161.5 \\
139.6 \\
\text { M X S 6.33 }\end{array}$ & $\begin{array}{c}91.1 \\
113.4 \\
172.1 \\
151.1 \\
146.5\end{array}$ & $\begin{array}{c}2.2 \\
3.0 \\
3.6 \\
3.7 \\
3.4 \\
3.2 \\
\mathrm{M} 0.06\end{array}$ & $\begin{array}{c}2.8 \\
3.3 \\
6.5 \\
5.1 \\
4.5 \\
4.4 \\
\text { S } 0.10 \\
\end{array}$ & $\begin{array}{l}2.5 \\
3.2 \\
3.4 \\
4.5 \\
3.9 \\
3.5\end{array}$ & $\begin{array}{l}2.7 \\
3.2 \\
5.7 \\
3.7 \\
4.2 \\
3.9 \\
\mathrm{M} \times \mathrm{S} 0.16 \\
\end{array}$ & $\begin{array}{l}2.5 \\
3.2 \\
4.0 \\
4.2 \\
4.0\end{array}$ \\
\hline
\end{tabular}

It may be concluded from the results that the crop roselle responded well to organic inputs viz., FYM, poultry manure, neem cake and vermicompost. Hence, these organic manures

\section{REFERENCES}

Adekiya, A.O., Agbede, T.M., Aboyeji, C.M. and Dunsin, O.(2017) Response of okra (Abelmoschusesculentus (L.) Moench) and soil properties to different mulch materials in different cropping seasons. Scientia Horticulturae, 217: 209-216.

Arsham, A. (2013) Effect of mineral and organic fertilizers on the growth and calyx yield of roselle (Hibiscus sabdariffaL.). International Journal of manures and fertilizer 2(12): 434436.

Atta, S., Seyni, H.H., Bakasso, Y., Lona, I. and Saadou, M. (2011) Yield character variability in roselle (Hibiscus sabdariffa L.). African Journal of Agricultural Research 6(6): 1371-1377.

Awodoyin, R.O., Ogbeide, F.I. and Oluwole, O. (2007) Effect of three mulch types on growth and yield of tomato and weed suppression in Ibadan, Rainforest-Savana transition zone of Nigeria. Tropical Agricultural Research and Extension 23(2): 112- 117.

Haruna, I.M., Maunde, S.M. and Yahuza, S. (2011) Growth and calyx yield of roselle (Hibiscus sabdariffa L.) as affected by poultry manure and nitrogen fertilizer rates in the southern guinea savanna of Nigeria. Canadian Journal of Pure and Applied Sciences 5(1): 1345-1348.

Kamalakannan, S., Sureshkumar, S., Kumar, S., Sudhagar, R. and Venkatesan, S. (2019) Influence of fertigation and mulching on can be utilized for effective production. Weed control by any means of mulching augmented the growth and yield of roselle.

growth characters at harvest stage in okra. International Journal of Research and Analytical Review 6(2): 812-815.

Kujur, A., Upadhyaya, H.D., Bajaj, D., Gowda, C.L.L., Sharma, S., Tyagi, A.K. and Parida, S.K. (2016) Identification of candidate genes and natural allelic variants for QTLs governing plant height in chickpea. Scientific Reports 6: 27968.

Panda, D., Padhiary, A.K. and Mondal, S. (2020) Effect of panchagavya and jeevamrit on growth and yield of tomato (Solanum lycopersicum L). Annals of Plant and Soil Research 22 (1): 80-85

Panse, V.G. and Sukhatme, P.V. (1978) Statistical methods for agricultural workers, Indian Council of Agricultural Research, New Delhi India.

Patidar, M. and Mali, A.L. (2004) Effect of farmyard manure, fertility levels and biofertilizers on growth, yield and quality of sorghum (Sorghum bicolor). Indian Journal of Agronomy, 49(2): 117-120.

Saravanapandian, P. (2005) Organic farming in sustaining soil health $-A$ review Agric. Rev., 26(2): 14-17.

Thangamuniyandi, M. and Kamalakannan, S. (2016) Effect of integrated nutrient management on yield and quality characters in ashgourd (Benincasahispida Cogn.) Cv. Co-1. Advances in life Sciences 5(3): 985-989. 